\title{
Problematika Pembelajaran Bahasa Indonesia di SMA Negeri 2 Toraja Utara pada Masa Pandemi Covid-19
}

\author{
Resnita Dewi \\ Universitas Kristen Indonesia Toraja \\ resnita@ukitoraja.ac.id
}

\begin{abstract}
Abstrak
Tujuan penelitian ini adalah (1) Mendeskripsikan problematika siswa SMA Negeri 2 Toraja Utara selama pembelajaran daring pada masa pandemi covid-19. (2) Mengetahui upaya yang dilakukan oleh siswa SMA Negeri 2 Toraja Utara dalam mengatasi ketidakpahaman pelajaran bahasa Indonesia selama pembelajaran daring pada masa pandemi covid-19. Jenis penelitian ini adalah penelitian kualitatif deskriptif. Populasi penelitian ini berjumlah 416 Siswa Kelas XI SMA Negeri 2 Toraja Utara. Sampel diambil 20\% dari jumlah populasi. Dengan demikian, maka sampel penelitian ini berjumlah 84 siswa. Teknik pengambilan sampel adalah teknik sampling, artinya pengambilan sampelnya peneliti mencampur subjek-subjek di dalam populasi sehingga semua objek dianggap sama. Teknik pengumpulan data melalui observasi, wawancara, dan angket. Analisis data dalam penelitian ini mengidentifikasi, menganalisis, mendeskripsikan data melalui wawancara dan angket. Hasil menunjukkan bahwa (1) Problematika siswa SMA Negeri 2 Toraja Utara selama pembelajaran daring pada masa pandemi covid-19 yaitu : (a) Perubahan proses pembelajaran bahasa Indonesia, (b) Gangguan jaringan yang tidak stabil membuat akses internet menjadi terbatas, (c) Siswa kurang memahami pembelajaran yang diberikan oleh guru karena hanya memberikan materi dan tugas tanpa adanya penjelasan, (d) Waktu belajar yang sangat singkat. (2) Upaya mengatasi ketidakpahaman pelajaran bahasa indonesia selama pembelajaran daring pada masa pandemi covid-19 yaitu dengan menyakannya kepada guru, dan teman. Jika siswa belum memahami penjelasan yang diberikan, langkah selanjutnya siswa memanfaatkan IT (Ilmu Teknologi dan Informasi). Sumber media tergolong atas dua kategori yaitu media cetak berupa buku dan media online (internet) berupa google dan youtube.
\end{abstract}

Kata Kunci: Problematika Pembelajaran Masa Pandemi Covid-19

\section{Pendahuluan}

Bahasa adalah untuk menyampaikan pikiran dan perasaan kepada orang lain, baik secara tertulis maupun secara lisan. Dengan penggunakan bahasa seseorang memiliki ciri khas yang sesuai dengan pertumbuhan dan perkembangannya. Pertumbuhan dan perkembangan seseorang dapat dipengaruhi oleh lingkungan masyarakat tempat tinggal yang berusaha mengembangkan potensi diri melalui proses pembelajaran yang tersedia pada jenis pendidikan tertentu. Dengan demikian individu memiliki potensi untuk berkembang, dan berusaha mengembangkan potensi melalui proses pendidikan pada tertentu.

Pengajaran bahasa Indonesia di sekolah bertujuan agar siswa terampil dalam berbahasa baik secara lisan maupun secara tulisan. Pengajaran bahasa merupakan kegiatan yang dilakukan guru dalam menyampaikan pengetahuan tentang bahasa dan sastra Indonesia. Selain itu untuk meningkatkan pengetahuan tentang kebahasaan dan kesastraan kepada siswa dalam pengajaran bahasa menggunakan berbagai macam metode seperti diskusi, penugasan, ceramah, dll. Keberhasilan pengajaran bahasa Indonesia dipengaruhi oleh beberapa faktor, antara lain sarana dan prasarana, lingkungan sekolah, dan materi bahan ajar. Dalam pelaksanaannya pengajaran merupakan serangkaian kegiatan yang terpadu antara pelatihan, penugasan, metode, media, dan penyediaan 
kondisi dengan komponen kurikulum sebagai bahan ajar guru untuk mencapai tujuan tertentu.

Guru merupakan komponen utama dalam proses belajar mengajar. Para guru dituntut untuk dapat menerapkan metode yang tepat dalam pengajaran bahasa. Untuk membantu upaya pengajar dalam mengemban tugas sebaik-baiknya. Sehubungan dengan berjalannya proses belajar mengajar dunia diguncang dengan munculnya Corona Virus Disease 2019 (COVID-19). Adanya pandemi covid-19 yang melanda dunia termasuk Indonesia, berdampak pada berbagai aspek kehidupan salah satunya pendidikan.

Segala upaya sudah dilakukan pemerintah guna memperkecil kasus penularan covid19. Tak terpungkiri salah satunya adalah kebijakan belajar daring (dalam jaringan) untuk seluruh siswa/i hingga mahasiswa/i karena adanya pembatasan sosial. Hal Ini sesuai dengan keputusan Menteri Pendidikan dan Kebudayaan Republik Indonesia terkait Surat Edaran Nomor 4 Tahun 2020 tentang Pelaksanaan Kebijakan Pendidikan dalam Masa Darurat Penyebaran Covid-19. Pembelajaran daring adalah pembelajaran yang memanfaatkan teknologi atau jaringan internet dalam proses pembelajaran dapat menggunakan teknologi digital seperti, google classroom, whatsapp, zoom, google suite for education, ruang guru, dan zenius.

Berbagai inisiatif dilakukan untuk memastikan kegiatan belajar tetap berlangsung meskipun tidak adanya sesi tatap muka langsung. Dalam penerapannya pembelajaran daring memiliki banyak keterbatasan dan permasalahan yang terjadi di lapangan. Pertama, masih banyak guru yang mempunyai keterbatasan dari sisi akses maupun pemanfaatannya. Bagi guru yang belum paham akan teknologi pembelajaran daring akan menjadi suatu masalah. Kreativitas diperlukan dalam proses pembelajaran, artinya guru harus bisa mengkreasikan materi pelajaran agar mudah dipahami oleh siswa dengan pemanfaatan media yang ada. Kedua, kemandirian belajar siswa di rumah tidak dapat sepenuhnya dapat terlaksana dengan baik. Keterbatasan untuk tatap muka langsung dengan guru membuat siswa harus mandiri dalam memahami dan mengerjakan tugas tersebut. Tentu proses aktivitas belajar siswa tidak semulus dan semudah yang dibayangkan. Ketidakpahaman materi mungkin saja terjadi, apalagi jika materi yang diberikan membutuhkan penjelasan yang detail dan mendalam.

Ketiga, tugas yang diberikan guru membebani siswa. Pembelajaran daring selayaknya tidak membebani siswa dalam belajar, siswa seharusnya mempunyai kebebasan dalam aktivitas belajarnya. Tidak terbebani dengan banyaknya tugas dan waktu penugasan yang relatif pendek. Termasuk juga dikejar-kejar dengan batas waktu pengumpulan tugas yang diberikan oleh guru. Keempat, pembelajaran daring terkendala dengan signal internet yang tidak stabil dan penyediaan kouta data yang tinggi. Kita tahu, bahwa indonesia memiliki letak geografis yang beragam. Keragaman kondisi letak geografis rumah siswa yang beragam menjadi masalah terutama terkait kestabilan signal internet.

Permasalahan tidak hanya berhenti sampai disitu saja. Belajar daring yang membutuhkan pengetahuan tentang teknologi dan fasilitas dirasa tidak mudah bagi beberapa orang. Selain itu, peran guru yang mengajar sekaligus membimbing siswa disekolah, baik dalam hal karakter maupun moral, juga tidak terealisasi ketika siswa belajar dari rumah. Hal tersebut membutuhkan peran pihak lain dalam membimbing siswa salah satunya adalah orang tua. 


\section{Kajian Teori}

\section{Belajar dan Pembelajaran}

Burton (dalam Aunurrahman, 2011) menyatakan, "Belajar adalah modifikasi atau memperteguh kelakuan melalui pengalaman". Slameto (2003:13) menyatakan, "Belajar merupakan suatu proses usaha yang dilakukan seseorang untuk memperoleh suatu perubahan tingkah laku yang baru secara keseluruhan, sebagai hasil pengalamannya sendiri dalam interaksi dengan lingkungannya". Gagne (dalam Sunhaji, 2014:33-34) menjelaskan, pembelajaran adalah suatu usaha untuk membuat siswa belajar, sehingga situasi tersebut merupakan peristiwa belajar (event of learning) yaitu usaha untuk terjadinya perubahan tingkah laku dari siswa.

\section{Problematika Pembelajaran Bahasa}

Menurut Roshihuddin (2016:25), istilah "Problema atau problematika berasal dari bahasa Inggris yaitu "problematic" yang artinya persoalan atau masalah". Problematika pembelajaran adalah permasalahan yang mengganggu, menghambat, atau mempersulit bahkan mengakibatkan kegagalan dalam mencapai tujuan pembelajaran. Adanya faktor problematika pembelajaran yaitu faktor pendekatan pembelajaran, perubahan kurikulum, faktor kompetensi guru

\section{Media Belajar Dari Rumah (BDR)}

Pembelajaran di masa pandemi covid-19 harus tetap dilaksanakan walau dengan berbagai cara sehingga siswa dapat tetap belajar. Atsani (2020:37) menyatakan, ada berbagai contoh media pembelajaran online yang dapat digunakan dari rumah di masa pandemi covid-19 yaitu Google Class Room, Whatsapp, Zoom, Google Suite for Education, Ruang Guru, Zenius.

\section{Metode Penelitian}

Penelitian ini berjenis penelitian deskriptif kualitatif (Anggito \& Setiawan, 2018:11). Sumber data penelitian ini adalah siswa SMA Negeri 2 Toraja Utara. Teknik pengumpulan data melalui observasi, wawancara, dan angket. Analisis data dalam penelitian ini mengidentifikasi, menganalisis, mendeskripsikan data melalui wawancara dan angket.

\section{Pembahasan}

1. Problematika Siswa SMA Negeri 2 Toraja Utara Selama Pembelajaran Daring pada Masa Pandemi Covid-19

Berdasarkan hasil temuan dari pengisian insrument pengumpulan data berupa angket diketahui problematika yang dialami oleh siswa saat pandemi covid-19 yaitu :

a. Perubahan Proses Pembelajaran Bahasa Indonesia.

Jawaban hasil pengisian angket dari 84 siswa diketahui pandemi covid-19 memberikan pengaruh dan menjadi penghambat dilaksanakannya proses pembelajaran bahasa Indonesia di SMA Negeri 2 Toraja Utara. Berubahnya proses pembelajaran bahasa Indonesia, yang awalnya pembelajaran dilaksanakan di sekolah dengan tatap muka dan sekarang berubah menjadi pembelajaran daring (online) yang dilakukan dari rumah dengan istilah BDR (Belajar Dari Rumah). Hal ini di dukung dengan temuan di lokasi penelitian , 29 siswa sangat setuju, 43 siswa setuju, 4 siswa tidak setuju, 8 siswa sangat tidak setuju. Hal ini diperkuat dengan pernyataan hasil wawancara dengan 36 siswa. Kemudian peneliti mengkualifikasi data menjadi 4 siswa yang memiliki kesamaan dalam menjawab pertayaan yang menyatakan bahwa : 
MRS : Ya, pandemi covid-19 sangat mempengaruhi proses pembelajaran bahasa Indonesia karena adanya covid-19 maka pembelajaran di lakukan secara online dengan menggunakan aplikasi google classroom dan menurut saya belajar online sangat tidak optimal karena guru hanya memberikan materi dan tugas. Belum tentu siswa membaca dan memahami materi yang di berikan tanpa adanya penjelasan yang jelas.

SE : Cukup mempengaruhi proses pembelajaran bahasa Indonesia apalagi waktu masih belajar secara daring, banyak sekali materi yang kurang dimengerti dan dipahami. Pada saat ini walaupun kita sudah belajar tatap muka tetapi masih ada juga beberapa materi yang sulit di pahami karena waktu yang singkat.

VF : Ya, pandemi covid-19 mempengaruhi proses pembelajaran bahasa indonesia saya karena pelajaran sedikit terhambat dan dilakukannya dari rumah secara online. Saya tidak bisa langsung mengemukakan apa yang kurang di pahami karena proses pembelajaran yang virtual.

YT : Iya, karena selama pandemi lebih banyak BDR dari pada belajar tatap muka. Ketika BDR banyak materi yang kurang dimengerti dan pada saat belajar tatap muka waktu belajarnya sangat singkat yaitu 1 jam.

b. Gangguan Jaringan Yang Tidak Stabil Membuat Akses Internet Menjadi Terbatas.

Problematika yang dihadapi siswa selama pembelajaran daring adalah gangguan jaringan yang tidak stabil membuat akses internet menjadi terbatas. Hal tersebut sesuai dengan hasil wawancara dengan 36 siswa, peneliti mengkualifikasi data menjadi 5 siswa yang memiliki kesamaan dalam menjawab pertayaan sebagai berikut :

ODA : : kendalanya yaitu tugas yang kami kirim biasanya lewat dari Tenggat waktunya karena jaringan yang kurang baik.

RER, RRA : kendala yang hadapi covid-19 adalah kurang mengerti apalagi saat pembelajaran daring, terlebih pada materi pengayaan buku nonfiksi dan proposal dan juga terbatasnya akses internet.

ARR,AAT : secara pribadi kendala yang saya alami dalam pembelajaran selama masa pandemi covid-19 adalah koneksi jaringan internet dan kuota internet.

c. Siswa Kurang Memahami Pembelajaran Yang Diberikan Oleh Guru Karena Hanya Memberikan Materi Dan Tugas Tanpa Adanya Penjelasan

Hasil wawancara peneliti dengan jumlah 36 siswa mengenai pembelajaran daring yang diberikan oleh guru pada proses pembelajaran bahasa Indonesia, peneliti mengkualifikasi menjadi 5 siswa karena memiliki banyak kesamaan diantaranya sebagai berikut:

$M, Y Y S, W L \quad$ : tidak, karena guru tidak menjelaskan secara langsung materi yang diberikan melalui google classroom.

$R E$

: tidak, karena tugas yang diberikan tidak dijelaskan jadi susah untuk memahami tugas-tugas yang diberikan. Tugasnya biasa tidak disertai materi. 
:tidak, karena banyak kalimat-kalimat yang masih kurang dipahami. Karena dalam proses pembelajaran ada siswa yang cepat tangkap karena proses pembelajaran dari guru memang menjelaskan secara baik tanpa buru-buru begitupun sebaliknya.

d. Waktu Belajar Yang Sangat Singkat

Dari hasil pembelajaran bahasa Indonesia terdapat problematika yang dialami oleh siswa salah satunya waktu belajar sangat singkat akhirnya mempengaruhi siswa untuk memahami materi dan tugas yang diberikan. Pada wawancara peneliti dengan jumlah 36 siswa, peneliti mengkualifikasi menjadi 5 siswa sebagai berikut:

OR, VS : iya, banyak materi pelajaran yang saya tidak mengerti terutama terlebih terdapat pada semester 1 mengenai pengayaan buku nonfiksi dan cerpen. Pada semester 2 materi resensi buku. Karena proses pembelajaran sangat singkat yang dulunya 2 hingga 3 jam mendapat penjelasan dari guru beserta mata pelajaran sekarang hanya mendapat materi dari guru selama 1 jam.

$K R$

: susah untuk melakukan kerja kelompok dan mewawancarai seseorang yang dibutuhkan dan tidak mampu memahami sebagian materi karena waktu yang sangat singkat untuk belajar.

$W P$

: yang saya alami yaitu sulit memahami materi yang dikirim secara online terutama teks eksplanasi dan proposal. Kemudian pembelajaran berlangsung di dalam jaringan sehingga komunikasi antara siswa dan guru terbatas.

NSN

: ya, karena biasanya tatap muka menjadi daring yang membuat guru tidak langsung menjelaskan yang berpengaruh pada tingkat pemahaman. Walaupun dalam beberapa bulan ini SMAN 2 Toraja Utara sudah menjalankan pembelajaran tatap muka tetapi waktunya sangat terbatas.

2. Upaya Mengatasi Ketidakpahaman Pelajaran Bahasa Indonesia Selama Pembelajaran Daring pada Masa Pandemi Covid-19

Berdasarkan hasil temuan dari pengisian insrument pengumpulan data berupa angket, diketahui upaya yang dilakukan siswa SMA Negeri 2 Toraja Utara dalam mengatasi ketidakpahaman pelajaran bahasa Indonesia selama pembelajaran daring pada masa pandemi covid-19 yaitu dengan menyakannya kepada guru, dan teman. Jika siswa belum memahami penjelasan yang diberikan, langkah selanjutnya siswa memanfaatkan IT (Ilmu Teknologi dan Informasi). Sumber media tergolong atas dua kategori yaitu media cetak berupa buku dan media online (internet) berupa google dan youtube. Didukung dengan hasil pengumpulan data dari 84 responden, dengan keterangan 38 siswa sangat setuju, 44 siswa setuju, 2 siswa tidak setuju. Hal ini diperkuat dengan pernyataan hasil wawancara dengan 36 siswa. Kemudian peneliti mengkualifikasi data menjadi 5 siswa yang memiliki kesamaan dalam menjawab pertayaan yang menyatakan bahwa :

MN, TJB : Ya, saya lebih senang mencari solusi untuk materi yang kurang dipahami dengan berpedoman dengan buku cetak, terkecuali ada penjelasan yang kurang saya pahami dari buku cetak baru saya mencari penjelasan tambahan digoogle. 
Volume 7 Nomor 1 Tahun 2021

$D P$

: Solusi yang saya dapatkan mendengar informasi dari saudara saya jika mencari materi pembelajaran sebaiknya mencari di google schoolar.

OV, RS, YYS : Pada saat ada materi yang kurang saya pahami, saya tidak langsung menayakannya kepada guru melainkan bertannya dulu kepada teman kelas. Jika teman kelas saya tidak mengerti kemudian saya menanyakannya kepada guru. Apabila penjelasan yang diberikan masih belum bisa saya pahami

\section{Simpulan} barulah sama mencari penjelasan tambahan di google dan youtube.

Berdasarkan uraian pada bab-bab sebelumnya, maka pada bab $\mathrm{V}$ ini dapat diambil kesimpulan sebagai berikut :

1. Problematika siswa SMA Negeri 2 Toraja Utara selama pembelajaran daring pada masa pandemi covid-19 sebagai berikut :

a. Perubahan proses pembelajaran bahasa Indonesia sebab adanya covid-19 memberikan pengaruh dan menjadi penghambat dilaksanakannya proses pembelajaran bahasa Indonesia.

b. Gangguan jaringan yang tidak stabil membuat akses internet menjadi terbatas.

c. Siswa kurang memahami pembelajaran yang diberikan oleh guru karena hanya memberikan materi dan tugas tanpa adanya penjelasan.

d. Waktu belajar yang sangat singkat.

2. Upaya yang dilakukan oleh siswa SMA Negeri 2 Toraja Utara dalam mengatasi ketidakpahaman pelajaran bahasa indonesia selama pembelajaran daring pada masa pandemi covid-19 yaitu dengan menyakannya kepada guru, dan teman. Jika siswa belum memahami penjelasan yang diberikan, langkah selanjutnya siswa memanfaatkan IT (Ilmu Teknologi dan Informasi). Sumber media tergolong atas dua kategori yaitu media cetak berupa buku dan media online (internet) berupa google dan youtube.

1. Perlunya jadwal belajar yang akurat dan harus diketahui oleh semua siswa sehingga siswa dapat melakukan persiapan sebelumnya.

2. Perlunya siswa untuk memperhatikan lebih serius mengenai pembelajaran sehingga siswa tidak tertinggal update terbaru mengenai absensi maupun tugas yang diberikan guru.

3. Perlunya dibangun motivasi siswa untuk belajar daring dikarenakan guru tidak dapat membimbing siswa secara langsung sehingga siswa harus belajar secara mandiri. 


\section{Daftar Pustaka}

Afifah, N. (2017). Problematika Pendidikan Di Indonesia. Jurnal Ilmiah Pendidikan Dasar, Vol. I, 53-62.

Anugrahana, A. 2020. Hambatan, Solusi, dan Harapan. Pembelajaran Daring Selama Pandemi Covid-19 Oleh Guru Sekolah Dasar. Jurnal Scholaria, Volume 10, Nomor 3.

Apriliana, S. (2020). Problematika Pembelajaran Daring Pada Siswa Kelas IV MI. Institut Agama Islam Negeri Salatiga. ISSN 2527-9610. (http://digiilib.uinsgd.ac.id). diakses 4 April 2021.

Arifin, M. (2021). "Problematika Peran Orang Tua Dalam Mendampingi Anak Belajar Bahasa Indonesia Pada Masa Pandemi Covid-19.(Skripsi thesis)". Tersedia dari Electronic Theses and Dissertation. Universitas Muhammadiyah Surakarta. (http://eprints.ums.ac.id/id/eprint/88958). Diakses 31 Maret 2021.

Ashari, M. (2020). Proses Pembelajaran Daring di Tengah Antisipasi Penyebaran Virus Corona Dinilai. (https://www.pikiranrakyat.com/pendidikan/pr01353818/proses-pembelajaran-daring-ditengah-antisipasi-penyebaran-virus-corona). Diakses 3 April 2021.

Atsani, Z. (2020). Transformasi Media Pembelajaran Pada Masa Pandemi Covid19. Jurnal Studi Islam. Vol.1, No.1. e-ISSN: 2721-4931. LP2M NW. Lombok Timur.

Aunurrahman. (2011). Belajar dan Pembelajaran. Bandung: Alfabeta.

Basar, A. M. (2021). Problematika Pembelajaran Jarak Jauh Pada Masa Pandemi Covid-19. Edunesia : Jurnal Ilmiah Pendidikan.Vol. 2 No. 1.Hal.208-218. ISSN 2722-7790. (https://doi.org/10.51276/edu.v2i1.112). Diakses 6 April 2021.

Darmalaksana, W. dkk (2020). Analisis Pembelajaran Masa Online WFH Pandemi Covid-19. Karya Tulis Ilmiah (KTI), Bandung: UIN Sunan Gunung. (http://digiilib.uinsgd.ac.id). Diakses 4 April 2021).

Hakim. (2016). Macam-Macam Media Komunikasi - Fungsi. Diakses (http://pakarkomunikasi.com/macam-macam-media-komunikasi).

20 Mei 2021.

Harmuni. (2008). Refleksi dan Motivasi Belajar Mengajar. Surabaya. Prenada Media Grup.

Ibrahim dan Syaodih. (2003). Perencanaan Pengajaran. Jakarta: Rineka Cipta.

Jaelani, A. dkk. (2020). Penggunaan Media Online Dalam Proses Kegiatan Belajar Mengajar PAI Dimasa Pandemi Covid-19 (Studi Pustaka Dan Observasi Online). Jurnal IKA, Vol. 8 No. 1, 55-68. (http://digilib.uinsby.ac.id). Diakses 6 April 2021

Kementrian Pendidikan dan Budaya RI. (2020). Peraturan Mendiknas tentang Pelaksanaan Kebijakan Pendidikan Dalam Masa Darurat Penyebaran Coronavirus Disease Covid-19 (Dokumen Surat Edaran Nomor 4 Tahun 2020). Jakarta,DKI: Kemendikbud.

Nizar, S. (2002). Filsafat Pendidikan Islam. Jakarta: Ciputat Pers.

Pengelola Web Kemendikbud. 2020. Kemendikbud Imbau Pendidik Hadirkan Belajar Menyenangkan Bagi Daerah yang Terapkan Belajar di Rumah. (https://Kemendikbud.go.id/main/blog/202.) Diakses 3 April 2021. 
Rahartri, (2019). “WhatsApp” Media Komunikasi Masa Kini. Visi Pustaka, Vol. 21, No.2, Agustus 2019. Diakses 17 Mei 2021.

Ramli, M. (2015). Hakikat Pendidikan dan Peserta Didik Tarbiyah Islamiyah. Volume 5 Nomor 1.

(http://jurnal.uinantasari.ac.id/index.php/tiftk/article/view/1825). Diakses 17 april 2021.

Riyanti, Yatim. (2001). Metodologi Penelitian. Surabaya: SIC.

Sanjaya, Ridwan. (2020). Refleksi Pembelajaran Daring Di Masa Darurat. Semarang: Universitas Katolik Soegijapranata

Sardiman, A.M. (2004). Interaksi dan Motivasi Belajar Mengajar. Jakarta: Rajawali Press.

Slameto. (2003). Belajar dan Pembelajaran. Jakarta : Rineka Citra.

Septirini Sekar Nusantari, S. A. (2020). Pembelajaran Bahasa Indonesia Secara Online Pada Masa Pandemi Covid-19 Di Sma Islam Terpadu Nur Hidayah Sukoharjo. Jurnal Bahasa, Sastra, dan Pengajarannya.Vol. 8, No. 2. Hal 206-214. ISSN 2714-9765. (http://journal.umsurabaya.ac.id/index.php/Axiologiya/index). Di akses 4 April 2021.

Sugiyono. (2011). Metode Penelitian Kualitatif Kuantitatif dan R\&D. Bandung: Alfabeta.

Suharto T. (2011). Perkembangan Peserta Didik. Surabaya. PT. Raja Grafindo Persada.

Sunhaji. (2014). Konsep Manajemen Kelas Dan Implikasinya Dalam Pembelajaran. Kependidikan, Vol. II No. 2.hal.33-34.

Tim Pengembang MKDP Kurikulum dan Pembelajaran 2011. Kurikulum dan Pembelajaran. Jakarta : PT. Raja Grafindo Persada

World Health Organization. (2020). Activities Guiding Principles for Immunization. Jenewa.

Yaumi, M. 2018. Media Dan Teknologi Pembelajaran. Jakarta : PRENADA MEDIA GROUP. 